was staged. Nobile had disappeared in the Arctic and half the governments of Europe were sending ships, ice-breakers, and aircraft to aid in the search for him. Amundsen believed that the Italians had treated him badly in the past, but the inherent greatness of the old idealist blazed out once more and he volunteered to lead a search party. On June 18 he left Norway in the large French Latham sea-plane piloted by Capt. Guilbaud, and manned by a crew of four. They disappeared to the northward ; wireless signals ceased after a few hours, and only the discovery of one of the floats of the machine off the Lofotons points to the way in which this great Norseman met his end sweeping out on his last voyage like a dead sea-king of old in his funeral ship.

By his great two feats of navigating the NorthWest Passage and reaching the South Pole, Amundsen had brought himself into the front rank of explorers, and his books on these expeditions must remain classics. Through his last book, "My Life as an Explorer," we are admitted to a more intimate acquaintance than has been possible in the case of other explorers ; but any glimpse of human weakness he gave in its pages must not be allowed to dim the greatness of his supreme foresight, fortitude, and success in discovery.

\section{Hugh Robert Mill.}

\section{Dr. Robert Knox.}

WE deeply regret to record the death of Dr. Robert Knox on Sept. 21, at sixty years of age. Knox was born at Leith, and obtained his medical education at Edinburgh and Guy's Hospital. After a short period of work in general practice he became definitely associated with the very young subject of medical radiology, and throughout the rest of his life we may say that he was linked with every important movement in this branch of medicine. With characteristic thoroughness his interests extended to every ramification of the subject; whether it was a question of hospital equipment or the association of the laboratory with clinical work or the status of radiologists, Knox would be found on the appointed committee, and he would be there in committee as member, secretary, or chairman. This went on for years, and until quite recently he appeared to carry the load lightly.

The societies and associations with which Knox worked, and by which his services were recognised in many very pleasant ways, were many. As secretary and then president of the Röntgen Society, he did splendid service during difficult years, and he finally supported its affiliation with the British Institute of Radiology, an institution he also helped to found.

Knox held important positions in the hospital world; he was at one time honorary radiologist to King's College Hospital, the Great Northern Central Hospital, Queen Alexandra Hospital, Millbank, and the Cancer Hospital, Fulham. It was at Fulham that his most important contributions to medical radiology were made. In radioNo. 3075, VoL. 122] diagnosis Knox had a great eye to technique, and contributed much to the development of serial radiography and its application to the study of the heart in action ; in radio-therapy he cautiously felt his way over many years in the treatment of cancer by $\mathrm{X}$-rays, and, realising the danger of heavy doses to the skin in administering doses to the deeper structures of the body, he devised a method of rotational focus by which this danger was largely eliminated.

In view of the many other claims upon his time, Knox's writings were considerable ; his book, "Radiography, X-ray Therapeutics, and Radium Therapy," appeared in 1915, and a second edition was quickly demanded, which led him to divide the book into two volumes, and this is now in its fourth edition.

Knox was well known and honoured in the radiological world; the American Röntgen Ray Society and the Scandinavian Röntgen Ray Society both elected him to their lists of honorary members. On the retirement of the late Dr. Deane Butcher, he became the joint editor of the Archives of Radiology, the name of which was years later changed to the British Journal of Radiology. His editorial colleagues will always remember how much Knox did for the old Archives. He won his way by sheer merit, and he was a man very much liked by his associates. Voluntary workers were always to be found in his hospital departments, attracted by the encouragement he gave them and by a friendship they rightly valued. S. Russ.

ThE sudden death of Dr. Stephanos Xanthoudides, announced in the Times of Sept. 21 by Sir Arthur Evans, is a blow to the archæologists not only of Greece but also of the whole world, who are indebted to him for his exertions in conjunction with Dr. Hatzidakis in instituting the Museum of Cretan Antiquities. It was outside this museum, according to Sir Arthur Evans's information, that his death took place. Although the museum at Candia represents his life work, he himself was an explorer and excavator of no mean achievement. His work on the vaulted tombs of Mesara in the south of Crete was an illuminating contribution to the history of the early eulture of the island. He had also devoted himself to the exploration of its later history, and was an authority on its remains of the Byzantine Age. It is satisfactory to know that he had completed the reparation of the damage to the museum caused by the disastrous earthquake of 1926 . His death will be a great loss to his many friends and fellow-workers of all nationalities.

WE regret to announce the following deaths :

Prof. D. Noël Paton, F.R.S., until recently Regius professor of physiology in the University of Glasgow, on Sept. 30, aged seventy years.

Sir Henry Wickham, who succeeded in obtaining seeds of Hevea from the Upper Amazon which were successfully grown at Kew and distributed in the East, thus starting the plantation rubber industry, on Sept. 27, aged eighty-three years. 